\title{
Effect of Foliar Spray with Some Growth Stimulants on Growth, Productivity and Quality of Cucumber Plants Grown under Greenhouse Conditions
}

Hadeer, H. E. Bahloul; Nadia, S. A. Shafshak; El Nagar M. Mahran and Zaki, M. El-Said

Corresponding author: hadeer.hammam@fagr.bu.edu.eg

\begin{abstract}
A field experiment was carried out under plastic greenhouse at the experimental farm of vegetables, Faculty of Agriculture, Benha University during the two successive winter seasons of 2019/2020 and 2020/2021 to study the effect of foliar application with some growth stimulants, i.e., amino acids at 0.5 and $1 \mathrm{~g} / \mathrm{L}$, zinc at 1 and $2 \mathrm{~g} / \mathrm{L}$, caboron ${ }^{\circledR}$ (calcium boron) at 2 and $4 \mathrm{ml} / \mathrm{L}$, salicylic acid at 0.5 and $1 \mathrm{~g} / \mathrm{L}$, chitosan at 2 and $4 \mathrm{~g} / \mathrm{L}$ and lithovit ${ }^{\circledR}$ (micronized calcium carbonate) at 1 and $2 \mathrm{~g} / \mathrm{L}$ in addition to the control treatment (sprayed with distilled tap water) on vegetative growth, chemical constituents of plant foliage, productivity and fruit quality of cucumber plants of Craze hybrid. The experiment was designed as complete randomized block with 3 replicates. Obtained results showed that treating the plants with the higher level of amino acids i.e.1 g/L followed by caboron at $4 \mathrm{ml} / \mathrm{L}$ exhibited the highest values for all measured vegetative growth aspects, photosynthetic pigments, macronutrients content and total carbohydrates. As for yield productivity, the highest number of fruits/plant, fruit yield/plant and total fruit yield/m2 were obtained as a result of spraying cucumber plants with Caboron ${ }^{\circledR}$ at $4 \mathrm{ml} / \mathrm{L}$ every 10 days intervals starting 21 days form transplanting with the best physical and chemical properties.
\end{abstract}

Key words: Growth stimulants, Chitosan, Lithovit, Salicylic acid, Amino acids.

\section{Introduction}

Cucumber (Cucumis sativus L.) is an important vegetable crop and one of the most popular members of the cucurbitaceae family. It is eaten as fresh vegetable which is an excellent source of vitamin $\mathrm{K}$, lignin, flavonoids, triterpenes, antioxidants and minerals (Maheshwari et al., 2014). Cucumbers have very low calories, and contain no cholesterol or saturated fats. It is one of the most important and consuming vegetables, fourth one, after tomatoes, onions and cabbage (Crosby, 2008). Cucumber is the second crop, after watermelon, of the cucurbit family that is widely cultivated in the Middle East. In Egypt the cultivated area of cucumber was 59720 fed., producing 561369 ton with an average yield of 9.41 ton/feddan (FAO, 2019). After the Egyptian Ministry of Agriculture, Economic Affairs Sector, Bulletin of Agricultural Statistics, the average number of greenhouses cultivated by cucumber is 29876 thousand greenhouses, reached an area approximately $11128071 \mathrm{~m}^{2}$, (2018-2019).

Cucumber is a thermophilic and frost susceptible crop, grown best at a temperature above $20^{\circ} \mathrm{C}$. Cucumber crop grows successfully under conditions of high light, humidity, soil moisture, temperature and fertilizers. Using the controlled as greenhouse cultivation is one of the most appropriate methods to increase production per unit area (ElAidy et al., 2007). The protective cultivation supports a favorable environment to cultivate desirable crop year round. A greenhouse traps the short wavelength solar radiation to create a favorable microclimate for higher productivity (Kumari, 2006). Increasing the productivity of cucumber fruits with high quality is considered an important aim that could be archived through using the foliar application of some stimulant substances.

Amino acids are a well-known stimulant which has positive effects on plant growth, yield and significantly mitigates the injuries caused by abiotic stresses (Kowalczyk and Zielony, 2008)

Zinc plays an important role in the production of biomass. Furthermore, zinc may be required for chlorophyll production, pollen function and fertilization (Kazemi, 2013)

Calcium is a major component of cell walls having $60-70 \%$ of its total tissue. It helps in maintaining cell wall integrity and membrane permeability. Calcium is the basic component of many enzymes and is considered as an important mineral that regulates fruit quality and enhances its post-harvest life through diminishing the physiological disorders like water core, bitter pit and internal breakdown (Siddique et al., 2017)

Boron as micro nutrient is one among the sixteen essential elements required for the completion of plant growth and life. Since, it play an important role in many metabolic processes like cell wall strengthening and development, cell division, sugar transport, hormone development, flower production, retention and fruit as well as seed development. (Bommesh et al., 2017)

Salicylic acid as an intracellular growth regulator and a growth promoter plays an important role in plant development (Giménez et al., 2017). It is well known that salicylic acid can be involved in plant physiological and biochemical processes including photosynthesis, ion absorption, membrane permeability, enzyme activity, flowering and plant growth and development (Hayat et al., 2007). 
Chitosan, a given name to a deacetylated form of chitin, is a natural biodegradable compound derived from crustaceous shells such as crabs and shrimps, whose main attributes corresponds to its polycationic nature (Bautista-Baños et al., 2006). An additional positive effect of chitosan coatings is related to its ability to extend the storage life of fruits and vegetables. Chitosan forms a semipermeable film that regulates the gas exchange and reduces transpiration losses and consequently fruit ripening is slowed down. Because chitosan is applied as a coating, generally respiration rate and hence water loss is reduced (Terry and Joyce, 2004).

Lithovit ${ }^{\circledR}$ is a micronized calcium carbonate. It contains magnesium carbonate (4\%) a source to magnesium which plays a role to chlorophyll synthesis, it also contains silica (5\%) that plays an important role in environmental stresses (Raven, 2003) and also contains calcium carbonate (75\%) decomposes to $\mathrm{CaO}$ and $\mathrm{CO} 2$ in leaves stomata, this $\mathrm{CO} 2$ increases the intensity of photosynthesis.

The present study aimed to investigate the effects of different foliar application treatments including amino acids, zinc, caboron, salicylic acid, chitosan and lithovit at two concentrations for each on plants vegetative growth, fruit yield and fruit quality of cucumber plants under greenhouse conditions.

\section{Materials and Methods}

A field experiment was carried out under plastic greenhouse at the research farm of vegetables, Faculty of Agriculture, Benha University during the two successive winter seasons of 2019/2020 and $2020 / 2021$ to study the effect of some different resources of foliar application i.e. amino acids, zinc, calcium boron, salicylic acid, chitosan and lithovit at two concentrations for each source on vegetative growth, chemical components of plant foliage, productivity and quality of cucumber. The used plastic greenhouse is $9 * 30 \mathrm{~m}$. Cucumber seeds of Craze hybrid were sown in seedling trays ( 84 cells) on October $1^{\text {st }}$ for the first season and October $15^{\text {th }}$ for the second one. Before transplanting the cucumber seedlings, a representative soil sample $(0-30 \mathrm{~cm}$ depth) was taken from the experimental field and Physical and chemical characteristics of the used soil are shown in Table 1. Physical analysis was estimated according to Jackson (1973) whereas, chemical analysis was determined according to Black $\boldsymbol{e t}$ al. (1982).

Table 1. The physical and chemical analysis of plastic greenhouse soil in 2019/2020 and 2020/2021 seasons.

\begin{tabular}{|c|c|c|}
\hline \multirow{2}{*}{ Soil properties } & \multicolumn{2}{|c|}{ Season } \\
\hline & $2019 / 2020$ & $2020 / 2021$ \\
\hline \multicolumn{3}{|l|}{ Physical analysis: } \\
\hline$\overline{\text { Sand }(\%)}$ & 21.00 & 20.50 \\
\hline Silt $(\%)$ & 24.00 & 24.50 \\
\hline Clay $(\%)$ & 55.00 & 55.00 \\
\hline Soil texture & Clay & Clay \\
\hline \multicolumn{3}{|l|}{ Chemical analysis: } \\
\hline$\overline{\mathbf{P h}}$ & 8.28 & 8.41 \\
\hline $\mathrm{EC}\left(\mathrm{mM} / \mathrm{cm}^{3}\right)$ & 1.49 & 1.57 \\
\hline Organic matter (\%) & 2.41 & 2.23 \\
\hline \multicolumn{3}{|l|}{ Soluble cations (meq/100 g soil) } \\
\hline $\mathrm{Na}+$ & 6.57 & 6.86 \\
\hline $\mathbf{C a}++$ & 0.55 & 0.66 \\
\hline Mg++ & 0.41 & 0.40 \\
\hline $\mathbf{K}+$ & 0.10 & 0.12 \\
\hline \multicolumn{3}{|l|}{ Soluble anions (meq/100 g soil) } \\
\hline $\mathrm{Cl}^{-}$ & 1.41 & 1.65 \\
\hline $\mathrm{HNO}_{3}^{-}$ & 1.30 & 1.60 \\
\hline $\mathrm{SO}_{4}^{--}$ & 4.92 & 4.79 \\
\hline \multicolumn{3}{|l|}{ Available elements } \\
\hline $\bar{N}(\mathbf{p p m})$ & 28.35 & 29.33 \\
\hline $\mathbf{P}(\mathbf{p p m})$ & 10.00 & 11.00 \\
\hline K (ppm) & 100.00 & 105.00 \\
\hline
\end{tabular}

The greenhouse was divided into five ridges. The width of each ridge was $1.5 \mathrm{~m}$. Seedlings were transplanted on two sides of each ridge at $30 \mathrm{~cm}$ spacing between plants within the row. The experimental plot area was $2 * 1.5 \mathrm{~m}^{2}$. Cucumber seedlings with three true leaves (20 days old) were transplanted in the greenhouse (on October $28^{\text {th }}$ for the first season and November $4^{\text {th }}$ for the second season). Culture practices such as drip irrigation, fertilization, diseases and insect control were applied according to the recommendations of Ministry of Agriculture, Egypt. During the growing period, 
plants were drip-irrigated twice a week to maintain $60 \%$ soil moisture. Plants were trained vertically by intertwining the main stem with a vertical piece of polyethylene twine suspended from a horizontal, overhead support wire $2 \mathrm{~m}$ above the plant rows.

The experiment was a randomized complete block design (RCBD) with three replicates.

The experiment in each season included thirteen treatments as follows:

- Amino acids (at 0.5 and $1 \mathrm{~g} / \mathrm{L}$ ).

- Zinc (at 1 and $2 \mathrm{~g} / \mathrm{L}$ ).

- Caboron (calcium boron) (at 2 and $4 \mathrm{ml} / \mathrm{L}$ ).

- Salicylic acid (at 0.5 and $1 \mathrm{~g} / \mathrm{L}$ ).

- Chitosan (at 2 and $4 \mathrm{~g} / \mathrm{L}$ ).

- Lithovit (micronized calcium carbonate) (at 1 and 2 $\mathrm{g} / \mathrm{L})$.

- Control (plants were sprayed with distilled tap water).

Three foliar applications were performed at 3 different growth stages (starting 21 days after planting and every 10 days intervals).

Data recorded:

1- Vegetative plant growth parameters:

Random samples of three plants from each plot were chosen after 60 days from transplanting and the following measurements were recorded: plant height $(\mathrm{cm})$, number of leaves/ plant, leaf area (cm2/plant), fresh weight of leaves ( $\mathrm{g}$ ) and picked leaves were dried at $70^{\circ} \mathrm{C}$ for 72 hours, and dry weight $\%$ per plant was calculated.

\section{2- Chemical constituents of plant foliage:}

Random samples of three plants from each plot were chosen after 60 days from transplanting and picked leaves were dried at $70^{\circ} \mathrm{C}$ for 72 hours the following measurements were recorded:

a. Total carbohydrates: It was determined as described in fruit chemical content by Stewart (1975) by using spectrophotometer.

b. Chlorophyll A, B and carotenoids: were measured with spectrophotometer (A.O.A.C., 2012).

c. Mineral elements: i.e. N, P, K, Ca, B, Zn. Nitrogen was determined in the digestion product, using the Micro-Kjeldahl method (Piper, 1947). Phosphorus was determined Spectrophotometrically in the above mentioned digestion product, according to the method described by King (1951). Potassium and calcium were determined in the above mentioned digestion product, using the Flame photometer according to the method described by Jackson (1967). While Zinc and Boron were determined in cucumber leaves by atomic absorption spectrophotometer as described by Chapman and Paratt (1961).

3- Fruit yield:

a. Number of fruits/plant: It was recorded as the total number of harvested fruits per plant throughout the growing season and was divided by the number of plants per plot. b. Total yield/ plant (kg): It was recorded as the total weight of the picked fruits throughout the harvesting season and was divided by number of plants per plot.

c. Total fruit yield $/ \mathbf{m}^{2}$ : Determined for all picked fruits and calculated as total fresh weight per quadrate meter.

\section{d. Physical Fruit quality:}

Data concerning fruit characteristics were collected when fruits reached the marketing fruit size after 70 days. Ten fruits were taken to determine the following parameters: average fruit length $(\mathrm{cm})$, fruit diameter $(\mathrm{cm})$, average fruit weight $(\mathrm{g})$ and average fruit firmness that was determined in a random sample of ten fruits for each experimental plot by using Digital's Penetrometer (PCEPTR.MITPC, USA) with a needle $8 \mathrm{~mm}$ in diameter.

e. Chemical Fruit quality:

A random sample of 10 fruits from each experimental plot at market stage was taken to determine the percentage of total soluble solids content (TSS\%) by using the hand refractmeter according to (A.O.A.C, 2012).

Vitamin C (mg /100 g): It was determined using the indicator of 2,6 dichlorophenol indophenol for titration as the method mentioned in A. O. A. C. (2012).

Reducing and non-reducing as well as total sugars (\%): They were determined by using the method described by Nelson (1944).

Statistical analysis:

The statistical analysis was carried out using SPSS, ver. 25 (IBM Corp. Released 2013). All data were statistically analyzed according to Snedecor and Cochran (1991) the differences means were compared by using the least significant difference test (L.S.D.) at 5\%. All statical determinations were made ah $\mathrm{P} \leq 0.05$.

\section{Results and Discussion}

\section{Vegetative growth characteristics:}

Data presented in Table 2 show the effect of foliar application with some growth stimulants such as amino acids, salicylic acid, calcium boron, zinc, chitosan and lithovit at two concentrations for each on vegetative growth characteristics of cucumber plants of Craze hybrid during the two winter seasons of study (2019/2020 and 2020/2021).

As for the effect of foliar spray treatments on vegetative growth characteristics such data in Table 2 indicate that all measured growth traits, i.e., plant height, number of leaves/plant, leaf area and dry matter \% were significantly affected as a result of spraying cucumber plant with amino acids (at 0.5 and $1 \mathrm{~g} / \mathrm{L}$ ), salicylic acid (at 0.5 and $1 \mathrm{~g} / \mathrm{L}$ ), caboron (at 2 and $4 \mathrm{ml} / \mathrm{L}$ ), zinc (at 1 and $2 \mathrm{~g} / \mathrm{L}$ ), chitosan (at 2 and $4 \mathrm{~g} / \mathrm{L}$ ), lithovit (at 1 and $2 \mathrm{~g} / \mathrm{L}$ ) three times during the growing season starting 21 days after transplanting and every 10 days by intervals compared with the control treatment. In this regard, 
treating the plants with amino acids followed by $\mathrm{Zn}$ and caboron at its higher used rated exhibited the highest values for all measured growth aspects compared with other tested treatments. In this connection, such superiority in morphological characteristics of plants due to spraying with amino acids, zinc or caboron may be due to their constituents that comprise amino acids, antioxidants and mineral constituents. In this respect, such constituents might play a main role as cell component that could affect cell formation, cell division and elongation that consequently led to enhance plant growth. Furthermore, the superiority of amino acids may be due to their important role in plant metabolism and protein assimilation which is necessary for cells formation and consequently increased fresh and dry matter of plant. Obtained results are similar to those obtained by Fahmy (2012), Bayoumi et al. (2009) and Kazemi (2013) on cucumber in case of amino acids, Ibrahim $\boldsymbol{e t}$ al. (2021) on strawberry in case of zinc, Elsharkawy et al. (2017) and Siddique et al. (2017) on cucumber in case of calcium, Abbasi et al. (2020) on cucumber and Ibrahim et al. (2021) on strawberry in case of boron, and Abd El-Hady and Abd-Elhamied (2018) on cucumber in case of chitosan and Abd ElHady and Abd-Elhamied (2018) on cucumber in case of lithovit.

Table 2. Effect of foliar application with some growth stimulants on vegetative growth of cucumber plants of Craze hybrid during (2019/2020) and (2020/2021) seasons.

\begin{tabular}{|c|c|c|c|c|c|c|c|c|c|c|}
\hline \multirow{2}{*}{ Treatments } & \multicolumn{2}{|c|}{ Plant height (cm) } & \multicolumn{2}{|c|}{ No. of leaves } & \multicolumn{2}{|c|}{ Leaf area $\left(\mathrm{cm}^{2}\right)$} & \multicolumn{2}{|c|}{$\begin{array}{c}\text { Leaf fresh weight } \\
\text { (g) }\end{array}$} & \multicolumn{2}{|c|}{$\begin{array}{c}\text { Leaf dry matter } \\
(\%)\end{array}$} \\
\hline & $\begin{array}{c}1^{\text {st }} \\
\text { season } \\
\end{array}$ & $\begin{array}{c}2^{\text {nd }} \\
\text { season } \\
\end{array}$ & $\begin{array}{c}1^{\text {st }} \\
\text { season } \\
\end{array}$ & $\begin{array}{c}2^{\text {nd }} \\
\text { season } \\
\end{array}$ & $\begin{array}{c}1^{\text {st }} \\
\text { season } \\
\end{array}$ & $\begin{array}{c}2^{\text {nd }} \\
\text { season } \\
\end{array}$ & $\begin{array}{c}1^{\text {st }} \\
\text { season } \\
\end{array}$ & $\begin{array}{c}2^{\text {nd }} \\
\text { season } \\
\end{array}$ & $\begin{array}{c}1^{\text {st }} \\
\text { season } \\
\end{array}$ & $\begin{array}{c}2^{\text {nd }} \\
\text { season } \\
\end{array}$ \\
\hline $\begin{array}{l}\text { Caboron } \\
\text { (at } 2 \mathrm{ml} / \mathrm{L} \text { ) }\end{array}$ & 117.8 & 143.9 & 24.3 & 33.0 & 178.0 & 215.8 & 4.2 & 5.3 & 17.3 & 18.6 \\
\hline $\begin{array}{c}\text { Caboron } \\
\text { (at } 4 \mathrm{ml} / \mathrm{L})\end{array}$ & 119.8 & 153.9 & 24.7 & 33.2 & 181.1 & 219.3 & 4.4 & 5.5 & 17.4 & 18.7 \\
\hline $\begin{array}{l}\text { Salicylic acid } \\
\text { (at } 0.5 \mathrm{~g} / \mathrm{L})\end{array}$ & 110.7 & 139.4 & 23.7 & 29.7 & 163.1 & 203.1 & 4.0 & 5.3 & 17.4 & 18.9 \\
\hline $\begin{array}{l}\text { Salicylic acid } \\
\quad \text { (at } 1 \mathrm{~g} / \mathrm{L})\end{array}$ & 116.7 & 141.7 & 23.7 & 30.4 & 170.7 & 210.2 & 4.1 & 5.3 & 17.7 & 19.2 \\
\hline $\begin{array}{l}\text { Amino acids } \\
\text { (at } 0.5 \mathrm{~g} / \mathrm{L})\end{array}$ & 125.0 & 156.1 & 25.7 & 33.6 & 188.8 & 263.3 & 4.8 & 5.9 & 19.5 & 22.0 \\
\hline $\begin{array}{l}\text { Amino acids } \\
\text { (at } 1 \mathrm{~g} / \mathrm{L})\end{array}$ & 127.2 & 157.8 & 26.3 & 37.9 & 194.4 & 289.7 & 4.9 & 6.1 & 20.2 & 23.7 \\
\hline $\begin{array}{c}\text { Zinc } \\
\text { (at } 1 \mathrm{~g} / \mathrm{L})\end{array}$ & 120.5 & 147.8 & 25.0 & 33.4 & 184.3 & 226.4 & 4.6 & 4.6 & 18.6 & 20.4 \\
\hline $\begin{array}{c}\text { Zinc } \\
\text { (at } 2 \mathrm{~g} / \mathrm{L})\end{array}$ & 121.7 & 155.0 & 25.0 & 29.9 & 186.7 & 236.1 & 4.6 & 5.7 & 18.7 & 20.6 \\
\hline $\begin{array}{l}\text { Lithovit } \\
\text { (at } 1 \mathrm{~g} / \mathrm{L} \text { ) }\end{array}$ & 105.0 & 132.8 & 24.0 & 32.1 & 150.7 & 157.8 & 4.03 & 5.2 & 17.0 & 17.7 \\
\hline $\begin{array}{l}\text { Lithovit } \\
\text { (at } 2 \mathrm{~g} / \mathrm{L} \text { ) }\end{array}$ & 108.9 & 136.7 & 21.7 & 32.9 & 158.6 & 169.6 & 4.1 & 5.3 & 17.3 & 17.9 \\
\hline $\begin{array}{l}\text { Chitosan } \\
\text { (at } 2 \mathrm{~g} / \mathrm{L} \text { ) }\end{array}$ & 103.3 & 128.3 & 21.0 & 28.3 & 142.9 & 214.2 & 3.4 & 5.0 & 15.8 & 17.1 \\
\hline $\begin{array}{l}\text { Chitosan } \\
\text { (at } 4 \mathrm{~g} / \mathrm{L})\end{array}$ & 104.5 & 130.6 & 23.3 & 28.6 & 149.1 & 135.3 & 3.7 & 5.1 & 16.3 & 17.3 \\
\hline Control & 95.5 & 95.6 & 19.0 & 23.6 & 141.4 & 123.2 & 3.3 & 4.4 & 15.5 & 16.9 \\
\hline LSD at 0.05 & 23.7 & 23.7 & 5.4 & 6.1 & 48.9 & 78.7 & 0.67 & 1.31 & 1.95 & 4.89 \\
\hline
\end{tabular}

\section{Chemical constituents of plant foliage:}

Data presented in Table (3 and 4) show the effect of foliar application with studied growth stimulants at two concentrations for each source on chemical composition of cucumber plants of Craze hybrid during the two seasons of study $(2019 / 2020$ and 2020/2021).

The effect of spraying growth stimulant substances, i.e., amino acids (at 0.5 and $1 \mathrm{~g} / \mathrm{L}$ ), salicylic acid (at 0.5 and $1 \mathrm{~g} / \mathrm{L}$ ), caboron(at 2 and 4 $\mathrm{ml} / \mathrm{L}$ ), zinc (at 1 and $2 \mathrm{~g} / \mathrm{L}$ ), chitosan (at 2 and $4 \mathrm{~g} / \mathrm{L}$ ) and lithovit (at 1 and $2 \mathrm{~g} / \mathrm{L}$ ), on photosynthetic pigments (Chlorophyll a, b and carotenoids), total carbohydrates, nitrogen, phosphorus, potassium, calcium, zinc and boron content are presented in Tables 3 and 4. Obtained results show that all foliar sprayed substances significantly increased foliage chlorophyll, (a \& b) carotenoids, total carbohydrates, $\mathrm{N} \%, \mathrm{P} \%, \mathrm{~K}, \mathrm{Ca}, \mathrm{Zn}$ and $\mathrm{B}$ contents compared to the control. In this concern, spraying the plants three times starting 21 days after planting and every 10 days interval recorded the highest increments in all assayed photosynthetic pigments and $\mathrm{N}, \mathrm{P}, \mathrm{K}$ macronutrients as well as total carbohydrates while the highest contents in calcium and boron in plant foliage were gained by using foliar spray with Caboron at $4 \mathrm{ml} / 1$. Obtained results are nearly similar during both seasons of growth. Such increments in photosynthetic pigments and macro-nutrients may be due to the role of tested growth stimulants as antioxidants, its content of growth substances, its effect as anti-diseases infection and consequently 
keeping plant health along with increasing the role of assimilation of photosynthetic pigments and absorption of macro-nutrients which may be resulted in increasing their concentration in plant tissues. In this respect, the increments in macronutrients and carbohydrates as a result of using amino acids may be attributed to the role of such compounds in increasing the availability of macronutrients to plant absorption and or increasing the passive force in plants required for nutrients absorption and consequently increased its content in plant foliage. Furthermore, such tested organic compounds play a positive role on carbohydrates assimilation through the photosynthetic process and consequently increased plant foliage. In this regard, similar observations were recorded by Bayoumi et al. (2009) on cucumber in case of amino acids as well as Kazemi (2013) on cucumber and Ibrahim et al. (2021) on strawberry in case of zinc and Elsharkawy et al. (2017) on cucumber in case of calcium and Özkutlu et al. (2017) on cucumber in case of boron and finally Abd El-Hady and AbdElhamied (2018) on cucumber in case of chitosan.

Table 3. Effect of foliar application with some growth stimulants on chemical constituents of plant foliage of cucumber plants of Craze hybrid during (2019/2020) and (2020/2021) seasons.

\begin{tabular}{|c|c|c|c|c|c|c|c|c|}
\hline \multirow{2}{*}{ Treatments } & \multicolumn{2}{|c|}{$\begin{array}{c}\text { Chlorophyll A } \\
(\mathrm{mg} / \mathrm{L})\end{array}$} & \multicolumn{2}{|c|}{$\begin{array}{c}\text { Chlorophyll B } \\
(\mathrm{mg} / \mathrm{L})\end{array}$} & \multicolumn{2}{|c|}{$\begin{array}{c}\text { Carotenoids } \\
(\mathrm{mg} / \mathrm{L})\end{array}$} & \multicolumn{2}{|c|}{ Carbohydrate (\%) } \\
\hline & $\begin{array}{c}1^{\text {st }} \\
\text { season }\end{array}$ & $\begin{array}{c}2^{\text {nd }} \\
\text { season } \\
\end{array}$ & $\begin{array}{c}1^{\text {st }} \\
\text { season }\end{array}$ & $\begin{array}{c}2^{\text {nd }} \\
\text { season }\end{array}$ & $\begin{array}{c}1^{\text {st }} \\
\text { season } \\
\end{array}$ & $\begin{array}{c}2^{\text {nd }} \\
\text { season }\end{array}$ & $\begin{array}{c}1^{\text {st }} \\
\text { Season } \\
\end{array}$ & $\begin{array}{c}2^{\text {nd }} \\
\text { Season } \\
\end{array}$ \\
\hline $\begin{array}{c}\text { Caboron } \\
\text { (at } 2 \mathrm{ml} / \mathrm{L})\end{array}$ & 2.06 & 2.29 & 1.28 & 1.36 & 1.44 & 1.49 & 12.95 & 14.13 \\
\hline $\begin{array}{c}\text { Caboron } \\
\text { (at } 4 \mathrm{ml} / \mathrm{L})\end{array}$ & 2.12 & 2.35 & 1.34 & 1.41 & 1.48 & 1.54 & 13.14 & 14.36 \\
\hline $\begin{array}{l}\text { Salicylic acid } \\
\text { (at } 0.5 \mathrm{~g} / \mathrm{L})\end{array}$ & 1.92 & 2.17 & 1.19 & 1.27 & 1.37 & 1.39 & 12.32 & 13.74 \\
\hline $\begin{array}{l}\text { Salicylic acid } \\
\quad \text { (at } 1 \mathrm{~g} / \mathrm{L})\end{array}$ & 1.96 & 2.22 & 1.22 & 1.32 & 1.41 & 1.46 & 12.68 & 13.92 \\
\hline $\begin{array}{l}\text { Amino acids } \\
\text { (at } 0.5 \mathrm{~g} / \mathrm{L})\end{array}$ & 2.37 & 2.56 & 1.45 & 1.53 & 1.61 & 1.74 & 13.72 & 15.15 \\
\hline $\begin{array}{l}\text { Amino acids } \\
\text { (at } 1 \mathrm{~g} / \mathrm{L})\end{array}$ & 2.46 & 2.78 & 1.58 & 1.67 & 1.65 & 1.79 & 14.54 & 15.67 \\
\hline $\begin{array}{c}\text { Zinc } \\
(\text { at } 1 \mathrm{~g} / \mathrm{L})\end{array}$ & 2.24 & 2.44 & 1.37 & 1.46 & 1.53 & 1.61 & 13.21 & 14.43 \\
\hline $\begin{array}{c}\text { Zinc } \\
\text { (at } 2 \mathrm{~g} / \mathrm{L})\end{array}$ & 2.31 & 2.49 & 1.40 & 1.48 & 1.56 & 1.65 & 13.59 & 14.82 \\
\hline $\begin{array}{l}\text { Lithovit } \\
\text { (at } 1 \mathrm{~g} / \mathrm{L} \text { ) }\end{array}$ & 1.81 & 1.90 & 1.09 & 1.18 & 1.27 & 1.30 & 11.67 & 12.47 \\
\hline $\begin{array}{l}\text { Lithovit } \\
\text { (at } 2 \text { g/L) }\end{array}$ & 1.88 & 2.07 & 1.13 & 1.23 & 1.32 & 1.36 & 11.91 & 12.75 \\
\hline $\begin{array}{l}\text { Chitosan } \\
\text { (at } 2 \text { g/L) }\end{array}$ & 1.71 & 1.81 & 1.03 & 1.10 & 1.21 & 1.23 & 11.47 & 11.98 \\
\hline $\begin{array}{l}\text { Chitosan } \\
\text { (at } 4 \mathrm{~g} / \mathrm{L})\end{array}$ & 1.79 & 1.86 & 1.08 & 1.12 & 1.26 & 1.27 & 11.32 & 12.31 \\
\hline Control & 1.56 & 1.63 & 0.96 & 1.05 & 1.11 & 1.15 & 10.26 & 10.72 \\
\hline $\begin{array}{c}\text { LSD at } 0.05 \\
\text { for: }\end{array}$ & 0.10 & 0.13 & 0.26 & 0.12 & 0.10 & 0.05 & 0.69 & 1.30 \\
\hline
\end{tabular}


Table 4. Effect of foliar application with some growth stimulants on chemical constituents of plant foliage of cucumber plants of Craze hybrid during (2019/2020) and (2020/2021) seasons.

\begin{tabular}{|c|c|c|c|c|c|c|c|c|c|c|c|c|}
\hline \multirow{2}{*}{ Treatments } & \multicolumn{2}{|c|}{$\mathbf{N}(\%)$} & \multicolumn{2}{|c|}{$\mathbf{P}(\%)$} & \multicolumn{2}{|c|}{$\mathbf{K}(\%)$} & \multicolumn{2}{|c|}{$\mathrm{Ca}(\%)$} & \multicolumn{2}{|c|}{ Zn (ppm) } & \multicolumn{2}{|c|}{ B (ppm) } \\
\hline & $1^{\text {st }}$ & $2^{\text {nd }}$ & $1^{\text {st }}$ & $2^{\text {nd }}$ & $\mathbf{1}^{\text {st }}$ & $2^{\text {nd }}$ & $1^{\text {st }}$ & $2^{\text {nd }}$ & $1^{\text {st }}$ & $2^{\text {nd }}$ & $\mathbf{1}^{\text {st }}$ & $2^{\text {nd }}$ \\
\hline $\begin{array}{c}\text { Caboron } \\
\text { (at } 2 \mathrm{ml} / \mathrm{L})\end{array}$ & 2.47 & 2.64 & 0.38 & 0.41 & 2.52 & 2.61 & 1.05 & 1.24 & 51.90 & 55.30 & 71.30 & 75.20 \\
\hline $\begin{array}{c}\text { Caboron } \\
\text { (at } 4 \mathrm{ml} / \mathrm{L})\end{array}$ & 2.53 & 2.70 & 0.40 & 0.44 & 2.55 & 2.63 & 1.12 & 1.28 & 53.20 & 57.40 & 74.50 & 78.60 \\
\hline $\begin{array}{c}\text { Salicylic acid } \\
\text { (at } 0.5 \mathrm{~g} / \mathrm{L})\end{array}$ & 2.40 & 2.56 & 0.43 & 0.47 & 2.61 & 2.72 & 0.87 & 1.02 & 56.60 & $\mathbf{5 9 . 7 0}$ & 63.20 & 67.50 \\
\hline $\begin{array}{l}\text { Salicylic acid } \\
\quad \text { (at } 1 \mathrm{~g} / \mathrm{L})\end{array}$ & 2.45 & 2.72 & 0.46 & 0.49 & 2.67 & 2.74 & 0.92 & 1.05 & 58.30 & 61.20 & 65.40 & 69.30 \\
\hline $\begin{array}{l}\text { Amino acids } \\
\text { (at } 0.5 \mathrm{~g} / \mathrm{L})\end{array}$ & 2.67 & 2.94 & 0.44 & 0.50 & 2.63 & 2.80 & 0.81 & 0.92 & 61.40 & 63.60 & 66.70 & 71.10 \\
\hline $\begin{array}{l}\text { Amino acids } \\
\text { (at } 1 \mathrm{~g} / \mathrm{L})\end{array}$ & 2.75 & 2.92 & 0.48 & 0.53 & 2.71 & 2.86 & 0.84 & 0.97 & 63.20 & 65.70 & 68.50 & 72.60 \\
\hline $\begin{array}{c}\text { Zinc } \\
\text { (at } 1 \mathrm{~g} / \mathrm{L})\end{array}$ & 2.59 & 2.75 & 0.32 & 0.38 & 2.38 & 2.52 & 0.73 & 0.80 & 64.70 & 66.8 & 60.40 & 63.70 \\
\hline $\begin{array}{c}\text { Zinc } \\
\text { (at } 2 \mathrm{~g} / \mathrm{L})\end{array}$ & 2.62 & 2.81 & 0.35 & 0.40 & 2.43 & 2.56 & 0.77 & 0.85 & 67.10 & 69.50 & 61.90 & 65.20 \\
\hline $\begin{array}{l}\text { Lithovit } \\
\text { (at } 1 \mathrm{~g} / \mathrm{L} \text { ) }\end{array}$ & 2.32 & 2.46 & 0.31 & 0.34 & 2.35 & 2.44 & 0.98 & 1.12 & 47.50 & 51.90 & $\mathbf{5 7 . 8 0}$ & 62.10 \\
\hline $\begin{array}{l}\text { Lithovit } \\
\text { (at } 2 \mathrm{~g} / \mathrm{L} \text { ) }\end{array}$ & 2.36 & 2.51 & 0.33 & 0.36 & 2.41 & 2.47 & 1.03 & 1.17 & 49.20 & 52.40 & 59.20 & 65.30 \\
\hline $\begin{array}{l}\text { Chitosan } \\
\text { (at } 2 \mathrm{~g} / \mathrm{L} \text { ) }\end{array}$ & 2.25 & 2.35 & 0.27 & 0.30 & 2.12 & 2.31 & 0.71 & 0.75 & 45.80 & 49.30 & 54.90 & 58.40 \\
\hline $\begin{array}{l}\text { Chitosan } \\
\text { (at } 4 \text { g/L) }\end{array}$ & 2.29 & 2.38 & 0.29 & 0.32 & 2.24 & 2.36 & 0.73 & 0.78 & 46.40 & 50.10 & 55.60 & 60.30 \\
\hline Control & 2.17 & 2.24 & 0.24 & 0.28 & 2.01 & 2.18 & 0.69 & 0.74 & 42.50 & 45.60 & 53.50 & 56.80 \\
\hline $\begin{array}{l}\text { LSD at } 0.05 \\
\text { for: }\end{array}$ & 0.11 & 0.15 & 0.03 & 0.04 & 0.07 & 0.06 & 0.05 & 0.08 & 3.11 & 2.34 & 2.89 & 2.54 \\
\hline
\end{tabular}

3. Total fruit yield and its components:

Data tabulated in Table (5) show cleary the effect of foliar application with some growth stimulants such as amino acids, salicylic acid, caboron, zinc, chitosan and lithovit at two concentrations for each source on fruit yield of cucumber plants of Craze hybrid during the two seasons of study (2019/2020 and 2020/2021). Such data in Table (5) indicate that number of fruits/plant, fruit yield/plant fruit yield $/ \mathrm{m}^{2}$ were positively affected due to spraying the plants with all tested growth stimulants compared with the control treatment. Obtained results were nearly similar during the two seasons of study. In this connection, the highest number of fruits/plant, fruit yield/plant fruit yield $/ \mathrm{m}^{2}$ were obtained as a result of spraying plants with caboron either at 2 or $4 \mathrm{ml} / 1$ every 10 days interval starting 21 days from transplanting. In addition, treating cucumber plant with amino acids ranked second followed by salicylic acid with significant differences between both substances and caboron. In this respect, the effect of either lithovit or chitosan concerning yield components lay in among caboron, amino acids and salicylic acid on one side and unsprayed control treatment which produced the least yield components during both season on the other side. Such increments in fruit yield components due to treating the plants with tested natural products were connected with their effect on increasing the vegetative growth parameters (Table, 1), photosynthetic pigments and macro-nutrients (Tables, 2 and 3) which might affect plant growth and in turn increased its productivity. Also using such tested growth stimulants reduced the infected fruit percentages and number of days elapsed to flower anthesis and consequently increased the early and marketable produced yield. Furthermore, the higher yield in case of using caboron may be attributed to the role of calcium and boron in translocation of produced photosynthetic assimilates and its accumulation in storage organs (fruits) and in turn increase the number, weight and size of fruits which consequently positively affected produced yield. Also such increases are connected with the increase in vegetative growth which might be connected greatly with the productivity of plant. Obtained results are in parallel to those reported by Bayoumi (2009), Fahmy (2012), Shehata et al. (2016) on cucumber in case of amino acids, Kazemi (2013) on cucumber as well as Ibrahim et al. (2021) on strawberry in case of zinc and Siddique et al. (2017) on cucumber in case of calcium. In addition, Bragg et al. (2008), Esringu et al. (2011), Kazmi (2014), Rahman et al. (2016), Ahmadi et al. (2018), 
Rosa et al. (2018) on strawberry in case of boron, Bayoumi (2009) in case of salicylic acid, Pieta et al. (2003), Abu-Muriefah (2013) on bean and Kamel
(2013) on pea plants in case of chitosan and Byan (2014) on snap bean in case of lithovit, came to similar conclusion.

Table 5. Effect of foliar application with some growth stimulants on fruit yield and its components of cucumber plants of Craze hybrid during (2019/2020) and (2020/2021) seasons.

\begin{tabular}{|c|c|c|c|c|c|c|}
\hline \multirow{2}{*}{ Treatments } & \multicolumn{2}{|c|}{ No. fruits/plant } & \multicolumn{2}{|c|}{ Total yield/plant (kg) } & \multicolumn{2}{|c|}{ Total yield/m² $(\mathrm{kg})$} \\
\hline & $1^{\text {st }}$ season & $2^{\text {nd }}$ season & $1^{\text {st }}$ season & $2^{\text {nd }}$ season & $1^{\text {st }}$ season & $2^{\text {nd }}$ season \\
\hline $\begin{array}{l}\text { Caboron } \\
\text { (at } 2 \mathrm{ml} / \mathrm{L})\end{array}$ & 34.6 & 41.5 & 3.61 & 3.76 & 14.44 & 15.04 \\
\hline $\begin{array}{l}\text { Caboron } \\
\text { (at } 4 \mathrm{ml} / \mathrm{L} \text { ) }\end{array}$ & 38.0 & 40.1 & 4.11 & 3.84 & 14.80 & 15.36 \\
\hline $\begin{array}{l}\text { Salicylic acid } \\
\text { (at } 0.5 \mathrm{~g} / \mathrm{L})\end{array}$ & 37.0 & 42.9 & 3.34 & 3.49 & 13.37 & 13.96 \\
\hline $\begin{array}{l}\text { Salicylic acid } \\
\quad(\text { at } 1 \mathrm{~g} / \mathrm{L})\end{array}$ & 36.7 & 43.5 & 3.41 & 3.54 & 13.62 & 14.16 \\
\hline $\begin{array}{l}\text { Amino acids } \\
(\text { at } 0.5 \mathrm{~g} / \mathrm{L})\end{array}$ & 36.9 & 44.9 & 3.48 & 3.68 & 13.91 & 14.72 \\
\hline $\begin{array}{l}\text { Amino acids } \\
\text { (at } 1 \mathrm{~g} / \mathrm{L})\end{array}$ & 36.3 & 44.3 & 3.56 & 3.71 & 14.21 & 14.84 \\
\hline $\begin{array}{c}\text { Zinc } \\
\text { (at } 1 \mathrm{~g} / \mathrm{L} \text { ) }\end{array}$ & 36.2 & 41.5 & 3.05 & 3.27 & 12.19 & 13.08 \\
\hline $\begin{array}{c}\text { Zinc } \\
\text { (at } 2 \text { g/L) }\end{array}$ & 35.8 & 41.8 & 3.06 & 3.33 & 12.25 & 13.32 \\
\hline $\begin{array}{l}\text { Lithovit } \\
\text { (at } 1 \text { g/L) }\end{array}$ & 33.9 & 40.0 & 3.23 & 3.41 & 12.92 & 13.64 \\
\hline $\begin{array}{l}\text { Lithovit } \\
\text { (at } 2 \text { g/L) }\end{array}$ & 32.9 & 39.3 & 3.35 & 3.45 & 13.36 & 13.80 \\
\hline $\begin{array}{l}\text { Chitosan } \\
\text { (at } 2 \text { g/L) }\end{array}$ & 37.7 & 43.3 & 2.72 & 3.04 & 10.85 & 12.16 \\
\hline $\begin{array}{l}\text { Chitosan } \\
\text { (at } 4 \text { g/L) }\end{array}$ & 39.7 & 39.6 & 2.98 & 3.11 & 11.93 & 12.44 \\
\hline Control & 36.7 & 48.7 & 2.63 & 2.75 & 10.51 & 11.00 \\
\hline LSD at 0.05 for: & 3.83 & 5.01 & 0.37 & 0.08 & 0.41 & 0.34 \\
\hline
\end{tabular}

4. Physical fruit quality:

Data recorded in Table (6) show the effect of foliar application with studied growth stimulants at two concentrations for each source on physical fruit quality of cucumber plants of Craze hybrid during the two seasons of study (2019/2020 and 2020/2021).

With regard to the effect of tested foliar spray substances (Table 6), data reveal that spraying plants three times with caboron at 2 or $4 \mathrm{ml} / \mathrm{l}$, salicylic acid at 0.5 or $1 \mathrm{~g} / \mathrm{L}$, amino acids at 0.5 or 1 $\mathrm{g} / \mathrm{L}$, Zinc at 1 or $2 \mathrm{~g} / \mathrm{L}$, Lithovit at 1 or $2 \mathrm{~g} / \mathrm{L}$ and chitosan at 2 or $4 \mathrm{~g} / \mathrm{L}$ every 10 days interval starting 21 days after transplanting significantly increased average fruit length, diameter, weight and firmness compared with the control treatment. In addition, treating plants with caboron, especially at its higher rate $(4 \mathrm{ml} / \mathrm{L})$ exceeded all other tested natural substances and the control treatment during both season of growth. In this regard, the increment in fruit quality characteristics due to the application of caboron as a foliar spray may be due to its content of macro and micro elements, especially $\mathrm{Ca}, \mathrm{K}$ and $\mathrm{B}$ which might be considered as the determintal factors affecting fruit quality including fruit firmness. Obtained results regarding caboron affect are in line with those reported by Al-Hamzawi (2010), ElGawad (2013), Ekinci et al. (2015), Siddique (2017), Bommesh et al. (2017) and Ibrahim et al. (2021) regarding the positive effects of both $\mathrm{Ca}$ and B minerals on many physical properties of the fruits of various vegetable crops. Such increment in fruit parameters due to salicylic acid treatment may be attributed to its role on physiological and biochemical processes including photosynthesis, ion absorption, membrane permeability and enzyme activity which might led to the increase in up taking essential and absorbing water by roots which in turn increased fruit size (Preciado - Rangel et al. (2019) and Abbasi et al. (2020). Similar observations were recorded by Fahmy (2012) and Shehata et al. (2016) on cucumber in case of amino acids, Kazemi (2013) on cucumber and Ibrahim et al. (2021) on strawberry in case of zinc, Kamel (2013) on pea in 
case of chitosan and Byan (2014) on snap bean in case of lithovit.

Table 6. Effect of foliar application with some growth stimulants on fruit physical characteristics of cucumber plants of Craze hybrid during (2019/2020) and (2020/2021) seasons.

\begin{tabular}{|c|c|c|c|c|c|c|c|c|}
\hline \multirow{2}{*}{ Treatments } & \multicolumn{2}{|c|}{ Fruit length (cm) } & \multicolumn{2}{|c|}{$\begin{array}{c}\text { Fruit diameter } \\
(\mathrm{cm})\end{array}$} & \multicolumn{2}{|c|}{ Fruit weight (g) } & \multicolumn{2}{|c|}{$\begin{array}{c}\text { Fruit firmness } \\
\left(\mathrm{g} / \mathrm{cm}^{2}\right)\end{array}$} \\
\hline & $\begin{array}{c}1^{\text {st }} \\
\text { season }\end{array}$ & $\begin{array}{c}2^{\text {nd }} \\
\text { season }\end{array}$ & $\begin{array}{c}1^{\text {st }} \\
\text { season }\end{array}$ & $\begin{array}{c}2^{\text {nd }} \\
\text { season }\end{array}$ & $\begin{array}{c}1^{\text {st }} \\
\text { season }\end{array}$ & $\begin{array}{c}2^{\text {nd }} \\
\text { season }\end{array}$ & $\begin{array}{c}1^{\text {st }} \\
\text { season }\end{array}$ & $\begin{array}{c}2^{\text {nd }} \\
\text { season }\end{array}$ \\
\hline $\begin{array}{c}\text { Caboron } \\
\text { (at } 2 \mathrm{ml} / \mathrm{L})\end{array}$ & 15.7 & 14.7 & 3.4 & 2.7 & 104.3 & 91.4 & 281 & 316 \\
\hline $\begin{array}{c}\text { Caboron } \\
\text { (at } 4 \mathrm{ml} / \mathrm{L} \text { ) }\end{array}$ & 16.7 & 15.4 & 3.42 & 2.8 & 108.2 & 97.2 & 292 & 311 \\
\hline $\begin{array}{l}\text { Salicylic acid } \\
\text { (at } 0.5 \mathrm{~g} / \mathrm{L})\end{array}$ & 15.2 & 14.7 & 3.1 & 2.7 & 90.4 & 81.4 & 251 & 274 \\
\hline $\begin{array}{l}\text { Salicylic acid } \\
\text { (at } 1 \mathrm{~g} / \mathrm{L})\end{array}$ & 15.3 & 14.7 & 3.1 & 2.7 & 92.9 & 81.6 & 255 & 281 \\
\hline $\begin{array}{l}\text { Amino acids } \\
(\text { at } 0.5 \mathrm{~g} / \mathrm{L})\end{array}$ & 15.2 & 14.7 & 3.1 & 2.7 & 94.4 & 83.11 & 239 & 259 \\
\hline $\begin{array}{l}\text { Amino acids } \\
\text { (at } 1 \mathrm{~g} / \mathrm{L})\end{array}$ & 15.4 & 14.7 & 3.2 & 2.7 & 98.1 & 85.4 & 247 & 266 \\
\hline $\begin{array}{c}\text { Zinc } \\
\text { (at } 1 \mathrm{~g} / \mathrm{L} \text { ) }\end{array}$ & 14.3 & 14.2 & 3.0 & 2.6 & 84.2 & 78.9 & 236 & 248 \\
\hline $\begin{array}{c}\text { Zinc } \\
(\text { at } 2 \mathrm{~g} / \mathrm{L})\end{array}$ & 14.6 & 14.3 & 3.1 & 2.6 & 85.5 & 80.1 & 240 & 255 \\
\hline $\begin{array}{l}\text { Lithovit } \\
\text { (at } 1 \mathrm{~g} / \mathrm{L} \text { ) }\end{array}$ & 15.6 & 14.8 & 3.3 & 2.7 & 99.3 & 87.8 & 268 & 287 \\
\hline $\begin{array}{l}\text { Lithovit } \\
\text { (at } 2 \text { g/L) }\end{array}$ & 15.6 & 14.8 & 3.3 & 2.7 & 101.8 & 89.2 & 276 & 294 \\
\hline $\begin{array}{l}\text { Chitosan } \\
\text { (at } 2 \mathrm{~g} / \mathrm{L} \text { ) }\end{array}$ & 14.2 & 13.8 & 3.0 & 2.5 & 72.1 & 70.5 & 228 & 239 \\
\hline $\begin{array}{l}\text { Chitosan } \\
\text { (at } 4 \mathrm{~g} / \mathrm{L})\end{array}$ & 14.1 & 14.1 & 3.0 & 2.5 & 75.2 & 78.9 & 231 & 243 \\
\hline Control & 13.9 & 13.6 & 3.0 & 2.4 & 71.7 & 57.4 & 227 & 235 \\
\hline LSD at 0.05 for: & 0.34 & 0.88 & 0.16 & 0.28 & 2.16 & 6.08 & 8.55 & 10.96 \\
\hline
\end{tabular}

\section{Chemical fruit quality:}

Data presented in Table (7) indicate the effect of foliar application with studied growth stimulants at two concentrations for each source on chemical constituents of fruits, i.e., TSS\%, vitamin C and total, reducing, as well as non-reducing sugars percentages of cucumber fruits of Craze hybrid during the two seasons of study (2019/2020 and 2020/ 2021).

Concerning the effect of foliar spray treatments, the same data in Table 7 show that spraying cucumber plants three times starting 21 days after transplanting and every ten days interval with caboron at 2 andc $4 \mathrm{ml} / 1$, salicylic acid at 500 and $1000 \mathrm{ppm}$, amino acids at 0.5 and $1 \mathrm{~g} / \mathrm{L}$, Zinc at 1 and $2 \mathrm{~g} / \mathrm{L}$, Lithovit at 1 and $2 \mathrm{~g} / \mathrm{L}$ and chitosan at 2 and $4 \mathrm{~g} / \mathrm{L}$ significantly increased the concentrations of assayed organic constituents of fruits i.e., total soluble solids (T.S.S), vitamin C, reducing, non- reducing and total sugars compared to the control treatment during both season of study. In this regard, the highest concentration in all the assayed organic constituents was recorded in case of using caboron followed by amino acids and salicylic acid in a descending order, respectively. Such enhancing effect due to using such tested growth stimulants on measured chemical constituents may be attributed to its positive effects on photosynthetic rates which in turn might affect the accumulation of such chemical compounds induces in storage organs (plant fruits). Obtained results are coincided with those reported by Kowalzyk and Zielony (2008), Shehata et al. (2016) and Bommesh et al. (2017) in case of amino acids, Kazemi (2013) and Ibrahim et al. (2021) in case of zinc, Abd El-Hady and Abd-Elhamied (2018) in case of chitosan and Raven (2003) in case of lithovit. 
Table 7. Effect of foliar application with some growth stimulants on fruit chemical components of cucumber plants of Craze hybrid during (2019/2020) and (2020/2021) seasons.

\begin{tabular}{|c|c|c|c|c|c|c|c|c|c|c|}
\hline \multirow{2}{*}{ Treatments } & \multicolumn{2}{|c|}{ TSS (\%) } & \multicolumn{2}{|c|}{$\begin{array}{c}\text { Vit. C } \\
(\mathrm{mg} / 100 \mathrm{~g})\end{array}$} & \multicolumn{2}{|c|}{$\begin{array}{c}\text { Total sugars } \\
(\%)\end{array}$} & \multicolumn{2}{|c|}{$\begin{array}{c}\text { Reducing } \\
\text { sugars }(\%)\end{array}$} & \multicolumn{2}{|c|}{$\begin{array}{c}\text { Non reducing } \\
\text { sugars }(\%)\end{array}$} \\
\hline & $\begin{array}{c}1^{\text {st }} \\
\text { season }\end{array}$ & $\begin{array}{c}2^{\text {nd }} \\
\text { season }\end{array}$ & $\begin{array}{c}1^{\text {st }} \\
\text { season }\end{array}$ & $\begin{array}{c}2^{\text {nd }} \\
\text { season }\end{array}$ & $\begin{array}{c}1^{\text {st }} \\
\text { season }\end{array}$ & $\begin{array}{c}2^{\text {nd }} \\
\text { season }\end{array}$ & $\begin{array}{c}1^{\text {st }} \\
\text { season }\end{array}$ & $\begin{array}{c}2^{\text {nd }} \\
\text { season }\end{array}$ & $\begin{array}{c}1^{\text {st }} \\
\text { season }\end{array}$ & $\begin{array}{c}2^{\text {nd }} \\
\text { season }\end{array}$ \\
\hline $\begin{array}{c}\text { Caboron } \\
\text { (at } 2 \mathrm{ml} / \mathrm{L})\end{array}$ & 5.13 & 5.27 & 21.60 & 23.63 & 3.80 & 3.87 & 3.66 & 3.69 & 0.13 & 0.17 \\
\hline $\begin{array}{c}\text { Caboron } \\
\text { (at } 4 \mathrm{ml} / \mathrm{L})\end{array}$ & 5.33 & 5.53 & 23.10 & 26.90 & 3.82 & 3.88 & 3.67 & 3.69 & 0.14 & 0.18 \\
\hline $\begin{array}{l}\text { Salicylic acid } \\
\text { (at } 0.5 \mathrm{~g} / \mathrm{L})\end{array}$ & 4.90 & 5.10 & 18.70 & 18.90 & 3.69 & 3.77 & 3.56 & 3.62 & 0.12 & 0.14 \\
\hline $\begin{array}{l}\text { Salicylic acid } \\
\text { (at } 1 \mathrm{~g} / \mathrm{L})\end{array}$ & 4.97 & 5.17 & 19.50 & 20.20 & 3.78 & 3.83 & 3.62 & 3.65 & 0.15 & 0.17 \\
\hline $\begin{array}{l}\text { Amino acids } \\
\text { (at } 0.5 \mathrm{~g} / \mathrm{L})\end{array}$ & 5.00 & 5.17 & 20.10 & 21.50 & 3.79 & 3.84 & 3.64 & 3.67 & 0.14 & 0.16 \\
\hline $\begin{array}{l}\text { Amino acids } \\
\text { (at } 1 \mathrm{~g} / \mathrm{L})\end{array}$ & 5.00 & 5.23 & 20.90 & 22.10 & 3.79 & 3.85 & 3.64 & 3.67 & 0.14 & 0.17 \\
\hline $\begin{array}{c}\text { Zinc } \\
\text { (at } 1 \mathrm{~g} / \mathrm{L})\end{array}$ & 4.80 & 5.02 & 17.50 & 17.90 & 3.61 & 3.71 & 3.47 & 3.58 & 0.13 & 0.12 \\
\hline $\begin{array}{c}\text { Zinc } \\
\text { (at } 2 \mathrm{~g} / \mathrm{L})\end{array}$ & 4.87 & 5.07 & 18.20 & 18.50 & 3.69 & 3.74 & 3.56 & 3.60 & 0.12 & 0.13 \\
\hline $\begin{array}{l}\text { Lithovit } \\
\text { (at } 1 \mathrm{~g} / \mathrm{L} \text { ) }\end{array}$ & 4.77 & 5.00 & 15.80 & 16.30 & 3.57 & 3.59 & 3.44 & 3.47 & 0.12 & 0.11 \\
\hline $\begin{array}{l}\text { Lithovit } \\
\text { (at } 2 \mathrm{~g} / \mathrm{L} \text { ) }\end{array}$ & 4.77 & 5.00 & 16.40 & 17.20 & 3.59 & 3.61 & 3.48 & 3.47 & 0.10 & 0.13 \\
\hline $\begin{array}{l}\text { Chitosan } \\
\text { (at } 2 \mathrm{~g} / \mathrm{L} \text { ) }\end{array}$ & 4.53 & 4.67 & 13.10 & 13.90 & 3.19 & 3.24 & 3.05 & 3.08 & 0.13 & 0.15 \\
\hline $\begin{array}{l}\text { Chitosan } \\
\text { (at } 4 \text { g/L) }\end{array}$ & 4.77 & 4.93 & 13.70 & 14.60 & 3.36 & 3.43 & 3.21 & 3.29 & 0.14 & 0.13 \\
\hline Control & 4.30 & 5.10 & 12.50 & 12.80 & 3.13 & 3.18 & 2.99 & 3.04 & 0.13 & 0.13 \\
\hline LSD at 0.05 & 0.21 & 0.25 & 1.74 & 1.46 & 0.26 & 0.35 & 0.26 & 0.35 & 0.01 & 0.01 \\
\hline
\end{tabular}

Conclusion

Under such conditions of the experiment foliar spray with Caboron solution at $4 \mathrm{ml} / \mathrm{l}$ or amino acids at $1 \mathrm{~g} / \mathrm{L}$ three times every 10 days interval starting 21 days form transplanting were the most affective agricultural strategy for increasing vegetative growth, total fruit yield with best qualities.

\section{References}

A.O.A.C. 2012. Official Methods of Analysis Association of Official Analytical Chemists International, $19^{\text {th }}$ Ed., Maryland, USA.

Abbasi, F., A. Khaleghi and A. Khadivi, 2020. The Effect of salicylic acid on physiological and morphological traits of cucumber (Cucumis sativus L. cv. Dream). Gesunde Pflanzen 72:155-162.

Abd El-Hady, M. A. and A. S. Abd-Elhamied, 2018. Impact of foliar, mineral fertilization and some plant activators on cucumber growth and productivity. J. Plant Production, Mansoura Univ., 9(2): 193 -201.

Abu-Muriefah, S.S. 2013. Effect of chitosan on common bean (Phaseolus vulgaris L.) plants grown under water stress conditions. International Research Journal of Agricultural Science and Soil Science. 3(6): 192-199.

Ahmadi, E., M. K. Honnabyraiah, Venkat Rao and H. S. Sreekanth, 2018. Effect of integrated nutrient management on soil nutrient status, and leaf nutrient status of strawberry (Fragaria $\times$ ananassa Duch) C.V. "Sabrina" under polyhouse. Int. J. Pure App. Biosci. 6 (2): 287291.

Al-Hamzawi, M. K. 2010. Effect of Calcium Nitrate, Potassium Nitrate and Anfaton on Growth and storability of Plastic Houses Cucumber. American J. of Plant Physiology., 5(5): 278-290.

Bautista-Baños, S., A.N. Hernández-Lauzardo, M.G. Velázquez del Valle, M. HernándezLópez, E. Ait Barka, E. Bosquez-Molina, C.L. Wilson, 2006. Chitosan as a potential natural compound to control pre- and postharvest diseases of horticultural commodities. Crop Prot., 25: 108-118.

Bayoumi, Y.A., M.A. Abd Alla, A.K. Hatam, 2009. Impact of foliar application with some bio and chemical stimulants on growth, yield 
and some endogenous hormones of cucumber plants (Cucumis sativus L.). Minufiya J. Agric. Res., 34 (1): 177-190.

Black, C.A., D.O. Evans, LE. Ensminger, J.L. White, F.E. Clark and R.C. Dinauer, 1982. Methods of soil analysis. part 2. Chemical and microbiological properties. $2^{\text {nd }}$ ed. Soil Sci.,Soc. of Am. Inc. Publ., Madison, Wisconsin, U. S.A.

Bommesh, J.C., P. Irene Vethamoni, S. Kumar, K. Nagaraju, R. Goudar, A.K. Pandav 2017. Effect of boron levels on physiology and quality characters of greenhouse parthenocarpic cucumber (Cucumis sativus L.). Environment \& Ecology, 35 (2): 676-680.

Bragg, N.C., B.J. Chambers, J.S. Davies and I.R. Richards, 2008. The effects of increasing levels of boron on the growth and yield of strawberries grown in peat-based systems. Acta Hortic 779:205-212.

Brown, J. and O. Lilleland, 1946. Rapid determination of potassium and sodium in plant material and soil extracts by flame photometric. Proc. Amer. Soc. Hort. Sci., 48: 341- 346.

Byan, U.A. I. 2014. Influence of using some safety materials on water requirement and water use efficiency of snap bean plant. J. Agric. Sci., Ain Shams Uni., Cairo, 22 (2): 381-394.

Chapman, H.D. and P.F. Paratt, 1961. Methods of soil, plants and water analysis. Univ. California, Div. Agric. Sci. 314.

Crosby, L. 2008. Growth and consumer evaluation of Cucumis sativus L. cultivated in controlled environments. Texas Tech University. 44(2): 170.

Egyptian Ministry of Agriculture, Economic Affairs Sector, Bulletin of Agricultural Statistics. 2018-2019.

Ekinci M., A. Esringü, A. Dursun, E. Yildirim, M. Turan, M.R. Karaman and T. Arjumend, 2015. Growth, yield, and calcium and boron uptake of tomato (Lycopersicon esculentum L.) and cucumber (Cucumis sativus L.) as affected by calcium and boron humate application in greenhouse conditions. Turk J. Agric For 39: 613-632.

El-Aidy, F, A. El-Zawely, N. Hassan, M. ElSawy, 2007. Effect of plastic tunnel size on production of cucumber in delta of Egypt. Applied Ecology and Environmental Research, 5, 11-24.

El-Gawad, H. G. A., S. E. Elminiawy, and L. M. Gebrel, 2013. Effect of different nitrogen sources and chelated calcium on productivity and quality of common bean seeds. Research Journal of Agriculture and Biological Sciences. 9(5): 241-247.

Elsharkawy, A.M, Sanaa M. El-Araby, I. M. Ghoneim and Shimaa M. Hassan, 2017. Efficiency of different nitrogen levels and calcium spraying rates on vegetative growth, yield, and quality of cucumber under greenhouse conditions. Alex. J. Agric. Sci. 62 (6):53-59.

Esringü, A., M. Turan, A. Gunes, A. Eşitken and P. Sambo, 2011. Boron application improves on yield and chemical composition of strawberry. Acta Agriculturae Scandinavica, Section B-Soil \& Plant Science . 61(3): 245253.

Fahmy, M. A.. 2012. Effect of some treatments on growth, yield and fruit chemical compostion of melon and cucumber crops under sandy soils conditions. Fac. Agric., Cairo Univ..

Giménez, M.J., M. Serrano, J.M. Valverde, D. Martínez-Romero, S. Castillo, D. Valero, F. Guillén, 2017. Pre-harvest salicylic acid and acetylsalicylic acid treatments preserve quality and enhance antioxidant systems during postharvest storage of sweet cherry cultivars. J. Sci. Food Agric., 97, pp. 1220-1228.

Hayat, S. and A. Ahmad, 2007. Salicylic acid: biosynthesis, metabolism and physiological role in plants. In: Hayat S, Ahmad A (eds) Salicylic acid: a plant hormone. Springer, Dordrecht, pp 401. eBook ISBN 978-1-4020-5184-5.

IBM SPSS Statistics for Windows, Version 25.0. Armonk, NY: (IBM Corp. Released 2013).

Ibrahim, H.K.M. 2021. Effect of foliar application with calcium, boron and zinc on the yield and quality of strawberry fruits and post-harvest diseases. Ms.c. Thesis. Fac. Of Agric., AlAzhar Univ., Cairo.

Jackson, M.L. 1973. Soil Chemical Analysis. Printice-Hall of India. Privat Limited, New Delhi.

John, M.K. 1970. Colorimetric determination of phosphorus in soil and plant material with ascorbic acid. Soil Sci., 109: 214-220.

Kamel, A.S.M. 2013. Effect of bio-fertilization and some growth stimulants on growth, green yield and seed production of peas. Ph.D. Thesis. Fac. Agric., Benha Univ. 132 pp.

Kazemi, M. 2013. Effect of foliar application of iron and zinc on growth and productivity of cucumber. Bull. Env. Pharmacol. Life Sci., 2 (11): 11-14.

Kazemi, M. 2014. Pre-harvest foliar application of paclobutrazol, boric acid and gibberellic acid influnces vegetative growth, reproductive characteristics and quality of strawberry (Fragaria $\mathrm{x}$ ananassa Duch. Cv. Camarosa). Bull. Env. Pharmacol. Life Sci., 3 (4): 183-187.

Kowalczyk, K. and T. Zielony, 2008. Effect of Aminoplant and Asahi on yield and quality of lettuce grown on rockwool. Conf. of, biostimulators in modern agriculture, 7-8.

Maheshwari, R.K., L. Mohan, J. Malhotra, B. Updhuay, B. Rani, 2014. Invigorating efficacy of Cucumis sativus for healthcare and radiance. Int. J. Chem. Pharm. Sci,. 2(3): 737-744. 
Nelson, N., 1944. A photometric adaptation of the somogyi method for the determination of glucose. J. Biol. Chem 153:375-380.

Özkutlu, F., Ö. Ete, M. Akgün, F. Akdİn, Y. Tutuş and B. Özcan, 2017. Boron fertilization effects on strawberry plant for preventing decomposed shaped fruit generation and on mineral content of leaves. Akademik Ziraat Dergisi 6(2): 153-160.

Pieta, D.A., Pastucha and E. Patkowska, 2003. Antagonistic microorganisms and chitosan in bean (Phaseolus vulgaris L.) protection from diseases. Annales Universitatis Mariae curie Sklodowska. Sectio EEE, Horticultura 12:109118.

Preciado-Rangel, P., J. J. Reyes-Pérez, S. C. Ramírez-Rodríguez, L. Salas-Pérez, M. Fortis-Hernández, B. Murillo-Amador, E. Troyo-Diéguez. 2019. Foliar aspersion of salicylic acid improves phenolic and flavonoid compounds, and also the fruit yield in cucumber (Cucumis sativus L.). Plants, 8, 44.

Pregl, E. 1945. Quantitative organic micro analysis. $4^{\text {th }}$ ed. J. Chundril, London.

Rahman, M.M., M. Sahadat, Sk. Rahul, M.Z.K. Roni and A.F.M. Jamal Uddin, 2016. Effect of pre-harvest $\mathrm{b}$ and $\mathrm{Zn}$ spray on yield and quality of strawberry. International Journal of Business, Social and Scientific. 5(1): 41-46.

Raven, J.A. 2003. Cycling silicon-The role of accumulation in plants. New Phytol., 158, 419421.
Rosa, D., F. Villa, D.R. Stumm, J. Lucini, F. Corbari, T.F. Bueno and J. Egewarth, 2018. Boron fertilization on strawberry $\mathrm{cv}$. Camarosa. Revista Agrarian. 11(41): 211-218.

Shehata, S.A., H.A. Hassan, A.A. Tawfik and M.F. Farag, 2016. Improving the productivity and quality of the cucumber crop grown under greenhouse conditions using some stimulants and spraying amino acids. J. Plant Production, Mansoura Univ., 7 (4): 385 -392.

Siddique, S., G. Ayub, Z. Nawaz1, S. Zeb, Faiza S. Khan, Naveed Ahmad, A. Khan and Kamran Rauf, 2017. Enhancement of growth and productivity of cucumber (Cucumis sativus) through foliar application of calcium and magnesium. Pure Appl. Biol., 6(2): 402-411.

Snedecor, G.W. and W.G. Cocharn. 1991. Statistical methods. $8^{\text {th }}$ Ed., Lowa State Univ. press, Lowa. USA.

Stewart, E.A. 1975. Chemical Analysis of Ecological material. Black well Scientific Publication, Oxford.

Terry, L.A. and D.C. Joyce, 2004. Elicitors of induced disease resistance in postharvest horticultural crops: a brief review. Postharvest Biol. Technol., 32: 1-13.

Kumari, N., G.N. Tiwari and M.S. Sodha , 2006. Thermal Modelling for Greenhouse Heating by Using Packed Bed. International Journal of Agricultural Research, 1: 373-383. 


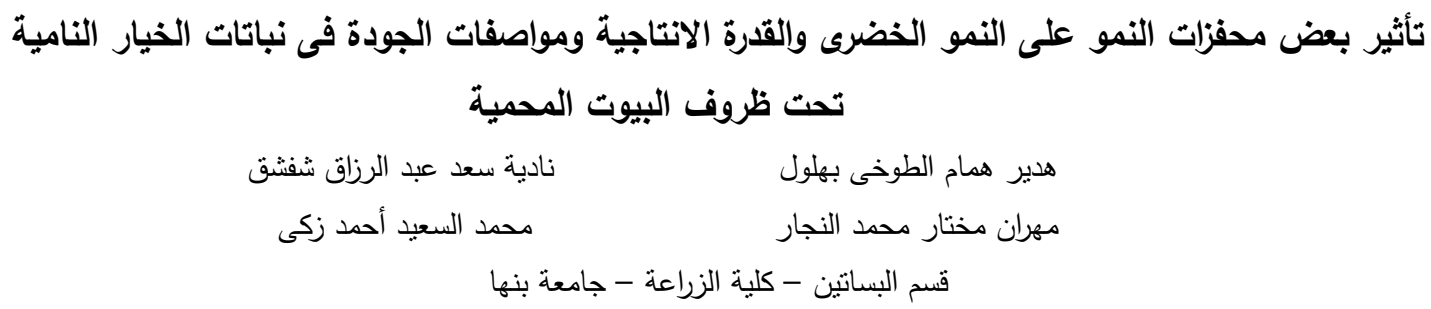

أجريت تجربة حقلية خلال الموسم الثنوى لعامى 2020/2019 و 2021/2020 فى الصوبة البلاستيكية بمزرعة بحوث الخضر

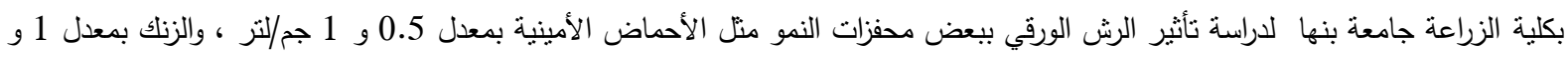

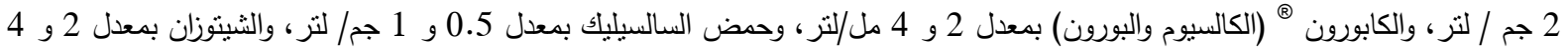

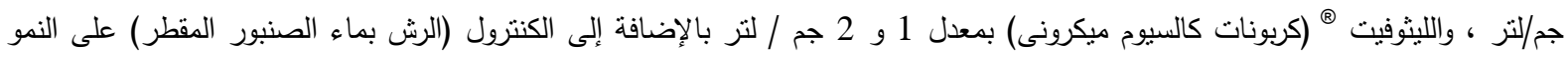

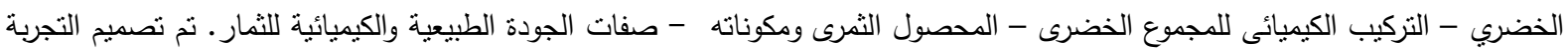

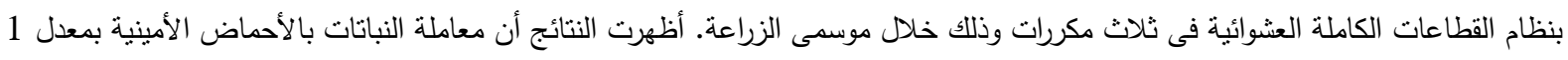

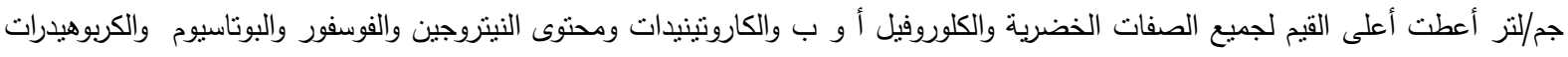

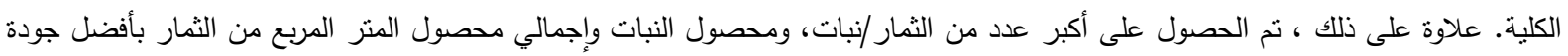

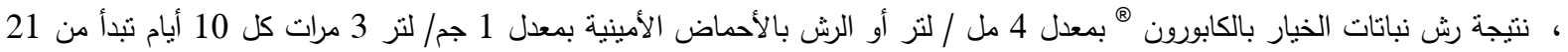
يومًا من الزراعة. الكلمات المفتاحية: محفزات النمو، الثيتوزان ، الليثوفيت ، حمض السالسيليك ، الأحماض الأمينية. 